\title{
Wind Energy at Remote Islands in Arctic Region - a Case Study of Solovetsky Islands
}

\author{
Rizwan Ghani $^{\mathrm{b}}$, Aleksei Kangash ${ }^{\mathrm{a}}$, Muhammad Shakeel Virk ${ }^{\mathrm{b}}$, Pavel Maryandyshev ${ }^{\mathrm{a}, *}$, Mohamad \\ Mustafa $^{\mathrm{b}}$ \\ ${ }^{a}$ Northern (Arctic) Federal University, naberezhnaya Severnoy Dviny 17, Arkhangelsk, Russia \\ ${ }^{b}$ UiT The Arctic University of Norway, Lodve Langes Gate 2, 8515 Narvik, Norway \\ *Email: p.marjyandishev@narfu.ru
}

\section{Abstract}

This paper describes a case study of wind resource assessment and wind park design at Solovetsky Islands, which are located in the Arctic region of northern Russia. The Solovetsky historical and cultural complex has been included in the list of UNESCO's World Heritage Sites. 18 year's data of wind climatology from the NASA Langley Research Center (LaRC) is used for wind resource assessment at Solovetsky Islands for two different wind park locations. Computational Fluid Dynamics (CFD) based numerical simulations are carried out for wind resource assessment and for the estimation of the resultant Annual Energy Production (AEP) for both locations. To better understand wind flow physics and effects of wind turbine wake effects, three different wake models are used for the numerical simulations. Analyses of seasonal weather effects on energy production show that wind power production at Solovetsky Islands is higher during winter period as compared to summer period, mainly due to higher wind speeds and air density at cold winter conditions. A preliminary case study about wind park layout optimization has also been carried out, where results show an increase in AEP with the optimization of wind park layout.

Keywords: Wind resource assessment; island; cold climate; CFD; wake effect; wind park layout.

\section{Introduction}

About $60 \%$ of the territory of Russia is not covered by the centralized electricity supply. The Russian Federation is characterized by a large number of island energy systems and remote settlements. The power supply of these areas is most often carried out by low-capacity power plants running on traditional organic (usually diesel) fuel. Electricity generation from diesel is very expensive because the fuel needs to be shipped over long distances [1]. Transportation in harsh weather conditions creates environmental problems associated with an increased risk of fuel spills and leaks [2,3]. In addition, diesel-generator sets have a negative impact on the environment due to their polluting emissions. The total capacity of diesel power plants operating in the far north of Russia is more than 3 million $\mathrm{kW}$, and the production of electricity is about 15 billion $\mathrm{kWh}$ in the Arctic zone of the Russian Federation, for which about 5-6 million tons of diesel fuel is imported annually [4]. Many diesel power stations have outdated equipment, as a result, they have high fuel consumption and, consequently, higher cost of energy production and more adverse environmental impact. In this 
regard, it is necessary to modernize the existing energy supply systems operating in harsh weather conditions, using modern and efficient technologies.

The Russian Arctic presents an interesting case for examining the challenges and opportunities related to the development of off-grid renewable energy sources (RES) [1]. It is necessary to create a reliable and efficient power supply system for remote territories that takes advantage of local renewable energy sources, primarily wind energy, considering that those territories are located in the zone of high wind potential.

A number of books, devoted to renewable energy sources, already published in Russia. In the book of prof. A.B. Alkhasov, the director of the Institute of Geothermal Problems of the Dagestan Scientific Center of the Russian Academy of Sciences, [5] reviewed the current state and prospects for the use of renewable energy sources, their energy, economic and environmental characteristics, given technological schemes of power plants, the principles of their work. In the book of prof. N.N. Baranov [6] considered methods for converting energy from renewable sources (wind, solar, biomass, ocean, hydrogen, geothermal energy). Physical and thermodynamic principles of energy conversion in photo and wind power installations are considered in the book of prof. A. da Rosa [7]. The book [8], written by the professor of the St. Petersburg Polytechnic University V.V. Yelistratov, covers the issues of storage of energy from renewable sources, as well as the operation of renewable energy facilities in grid and distributed generation. The book of O.S. Popel and V.E. Fortov, the Deputy Director and Director of the Institute for High Temperatures RAS respectively, [9] systematically examines all the most promising technologies for using renewable energy sources and the state of their development in the world.

Also, some articles on the topic of wind were published by Russian scientists. The articles [1011] analyze systems that can solve the problem of energy storage produced by wind turbines. Article [12] is devoted to the selection of optimal characteristics of a hybrid power plant for an isolated settlement. The work develops approaches to optimize power plants based on renewable energy sources and diesel generator sets. Scientists at the Peter the Great St. Petersburg Polytechnic University are engaged in the study and development of designs of wind power plants. In article [13], a review and analysis of engineering structures used in the design of wind power plants was carried out. The article [14] presents a description of the new wind power plant, its design and principle of operation.

But there are not enough articles on the assessment of the wind energy potential of the Russian territories. Any territory has unique environmental, ecological and economic conditions. Therefore, each case can be unique and requires individual complex study. Analysis of wind energy potential can contribute to the successful implementation of the project and prevent mistakes at the design stage. 
This paper describes a numerical case study of assessing wind resources for potential power production and implementing the wind energy as an alternative source of energy for a remote territory - the Solovetsky Islands (shown in Figure 1), which are located in the Arctic zone of the Russian Federation. On one of the islands there is the Solovetsky settlement, whose population is 898 people. And it has an isolated power supply system.

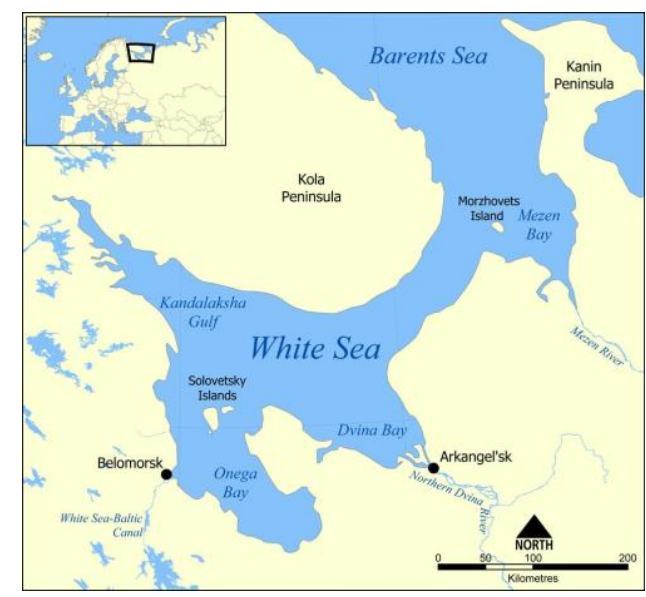

Fig. 1. Map of the Solovetsky Islands.

International experience demonstrates that off-grid RES systems can provide a technically feasible and economically sound solution to the energy challenges encountered by remote areas $[15,16]$. Science articles dedicated to studying of the possibility of introducing off-grid wind energy systems in Canada [17], Alaska [18] and India [19] were found.

One example of the successful implementation of wind turbines in remote islands is the Galapagos Islands in Ecuador. In January 2001, an oil tanker struck a reef and spilled about $570 \mathrm{~m}^{3}$ of diesel near San Cristobal - one of the inhabited islands of Galapagos, threatening the irreplaceable plants, birds, and marine life. After this disaster, a global renewable energy project on the Galapagos Islands was implemented in 2007 to reduce the greenhouse gas emissions and the risk of another oil spill at this UNESCO World Heritage Site. According to the project, three $800 \mathrm{~kW}$ capacity wind turbines were built. Between 2007 and 2015, wind turbines have supplied, on average, 30 percent of the electricity consumed on San Cristobal, replacing $8700 \mathrm{~m}^{3}$ of diesel fuel and avoiding 21000 tons of carbon dioxide emissions. In addition, monitoring results confirmed that turbines had not killed or injured any of the critically endangered Galapagos seabirds [20]. But this is an example of a territory, that is not in harsh climatic conditions.

At present, there is project towards the development of wind energy for remote territories in the Arctic region of Russia. A Wind-Diesel complex is being built in the Tiksi settlement (shown in Figure 2), which is expected to be completed at the end of 2019. The complex will consist of three wind turbines with a total capacity of $900 \mathrm{~kW}$, three diesel generators with a total capacity of $3 \mathrm{MW}$ 
and an energy storage system. The construction of this Arctic wind park will allow testing equipment in conditions of extremely low temperatures (down to $-40^{\circ} \mathrm{C}$ ) and strong winds (up to $60 \mathrm{~m} / \mathrm{s}$ ).

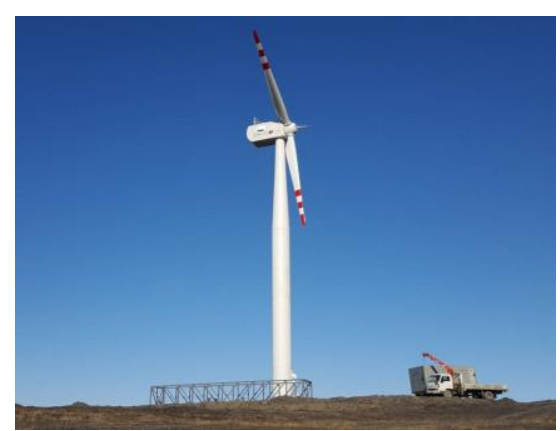

Fig. 2. Tiksi wind park under construction.

The aim of this paper is to assess wind resources of the Solovetsky Archipelago for power production potential. CFD based numerical simulations are carried out for the calculation of Annual Energy Production (AEP). The research method based on Computational Fluid Dynamics has shown its applicability in wind energy studies [21, 22]. For a comprehensive study of the issue, two different wind park sites, three wake turbulence models and seasonal climatologies were used for the numerical simulations. This study is a start towards the development of wind power in the remote islands in the Arctic region and will help both scientists and investors in future projects.

\section{Current situation}

At the Solovetsky Islands, the production of electrical energy is currently provided by two diesel power plants equipped with diesel-generator sets with a total capacity of $6.2 \mathrm{MW}$. The average daily electrical power in winter 2016 was $1440 \mathrm{~kW}$ and in summer was $721 \mathrm{~kW}$. The maximum daily electrical power was $1600 \mathrm{~kW}$. The ban on wood heating and the insufficient development of heating networks create an artificial mechanism for encouraging the use of electric heating. This increases the electrical load and, accordingly, the consumption of diesel fuel during the winter period (shown in Figure 3).

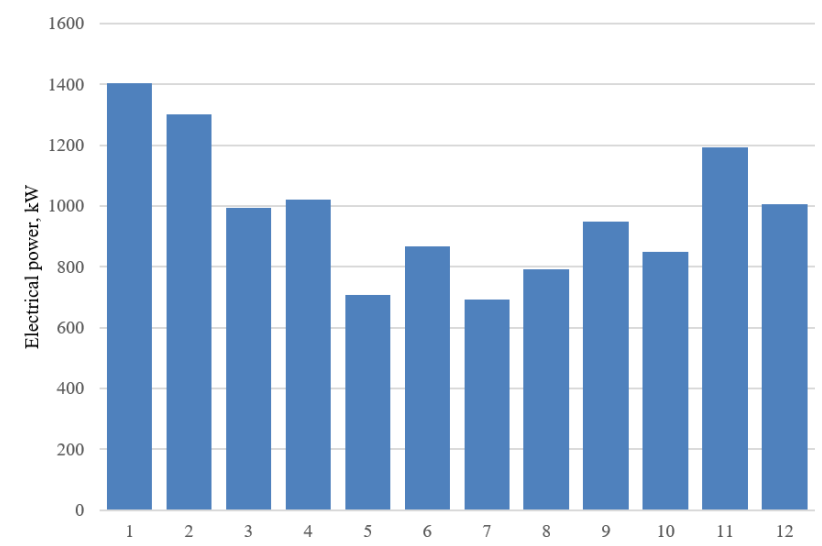

Fig. 3. Average monthly electrical power (2016). 
For the isolated energy system of the settlement, this is a case of irrational use of fossil fuel, which is delivered to the settlement only by sea. The difficulty of delivering fuel by the Northern way increases its cost several times. During the calculation of emissions of harmful substances from diesel-generator sets, operating data on the consumption of diesel fuel were used. Gross emissions of carbon monoxide, nitrogen dioxide and sulfur dioxide are shown in Figure 4.

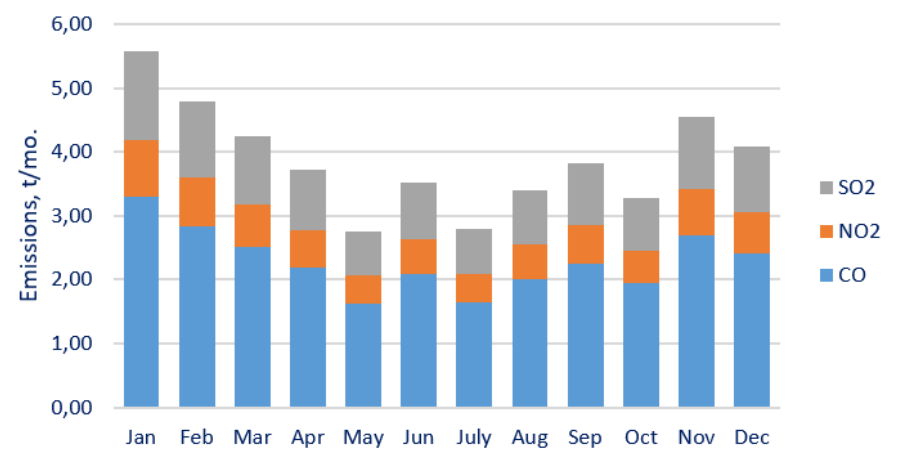

Fig. 4. Monthly emissions of pollutants at Solovetsky Archipelago (2016).

The rational option for providing a constant supply of energy to the Solovetsky Archipelago is to implement a scenario of increasing energy and environmental efficiency, which requires developing a system of effective mechanisms to encourage reduction of imported fuel consumption through the introduction of energy saving measures, increasing energy efficiency of facilities, and the use of local energy resources, including renewable energy. Due to the location of the Solovetsky Archipelago in the Far North, high wind potential exists on the islands, which makes it feasible to analyze the possibility of implementing wind power plants as a source of renewable energy.

\section{Wind Climatology Data}

Wind measurements data at an altitude of $50 \mathrm{~m}$ gathered over 18 years (2000-2017) was used for this study of wind resource assessment at the Solovetsky Islands. The data source is the NASA Langley Research Center (LaRC) POWER Project [23] funded through the NASA Earth Science/Applied Science Program and is based upon satellite observations and meteorological data from assimilation models. Measurements are represented by a global grid with a spatial resolution of $0.5^{\circ}$ latitude by $0.5^{\circ}$ longitude. These satellite and model-based products have been shown to be accurate enough to provide reliable meteorological resource data over regions where surface measurements are sparse or non-existent [23]. Wind speeds are divided into intervals, the step of which is equal to $1 \mathrm{~m} / \mathrm{s}$. Incoming wind directions are divided in 12 sectors, where the first sector is centered around the north. The wind rose characterizing the climatology of the Solovetsky Islands is shown in Figure 5. 


\section{Wind Park Terrain and Layout}

The terrain of the Solovetsky Islands is relatively flat, but in the northern part of the archipelago, there are large elevations. The highest point of the Bolshoy Solovetsky island is Sekirnaya mountain $(73.5 \mathrm{~m})$. Most of the islands are covered with forests. The average height of the trees is 15-18 meters. Two possible locations were chosen for potential wind park sites as shown in Figure 5. One of the reasons for this choice is the distance from historical objects considering that wind turbines should not disturb the view and create noise. The other reason is the open area, as deforestation on the UNESCO site is prohibited. Also, roads are nearby, which can also facilitate the transportation and installation of the wind turbines.
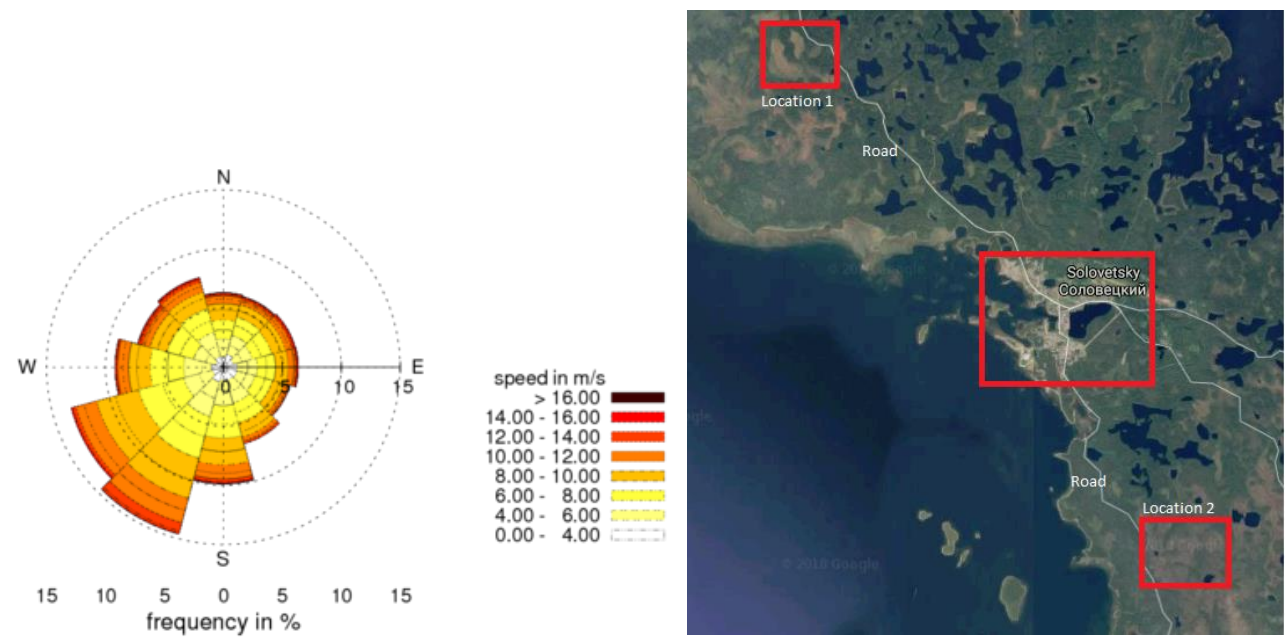

Fig. 5. Wind Rose (left) and Wind Park locations (right) for Solovetsky Islands.

\section{Numerical Setup}

CFD based numerical simulations in this study were carried out using WindSim software, which is a modern Wind Park Design Tool (WPDT) that helps to optimize the wind park energy production. A 3D terrain model of the wind park is generated, where the domain is discretized using a hexahedral numerical grid. Iterative numerical simulations of air flow behavior are performed by solving Reynolds Averaged Navier-Stokes equations (RANS). The energy equation is neglected during this study, as temperature is assumed constant in the region close to the ground surface. So, the exchange of heat and water vapor at Earth's surface is neglected. In order to account for surface roughness in the numerical simulations, Wieringa's classification is used. RNG-based k- $\varepsilon$ turbulence is used due to its better agreement with flow profiles and length of the separated flow region [24]. The detailed setup is shown in Table 1. The value of terrain surface roughness heights is read from the grid file in WindSim. The roughness height is used in the velocity profile log-law, given in equation (1):

$$
\frac{u}{u^{*}}=\frac{1}{\kappa} \ln z / z_{0}
$$


where $u$ is the wind velocity; $u^{*}$ is the friction velocity, $\kappa$ is von Kármán constant $(\kappa=0,435)$; $\mathrm{z}$ is the coordinate in the vertical direction; $z_{0}$ is roughness height. The wind park digital terrain model containing elevation and roughness data used for CFD simulations is shown in Figure 6.
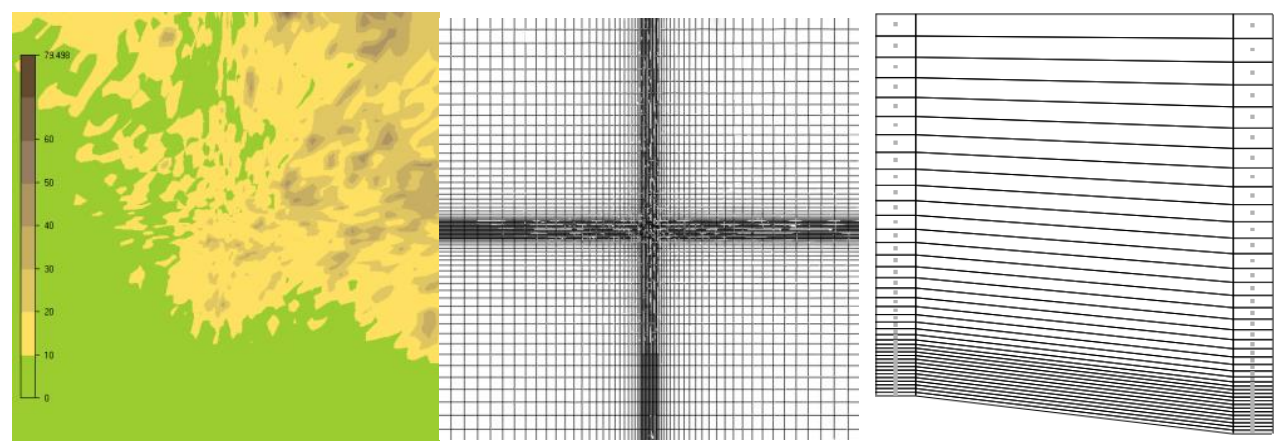

Fig. 6. Terrain elevation (m) (left) and horizontal and vertical grid resolution (right).

In this study, the wind park terrain corresponds to the mesoscale topology of the region around the wind park site locations. The areas selected for wind flow simulations is the section that involves different sizes in the direction of the flow to determine the influence of the natural formation of the region on the wind profile. Estimation of latitudinal and longitudinal extension of the domain is quite important because wind behavior will be directly affected by the surface shape, following the mass and momentum conservation equations. Three different wake loss models: 1) Jensen et al., 2) Larsen et al. and 3) Ishihara et al $[25,26]$ are used for this study. These wake models are used as they cover the inputs of different factors such as incoming wind turbine speed, downstream distance from the turbine, radial distance from turbine, rotor diameter, hub height and turbulence intensity [27]. These wake loss models are based on calculating the normalized velocity deficit, $\delta \mathrm{V}$, as described in equation (2):

where, $\mathrm{U}$ is the free stream velocity, and $\mathrm{V}$ is air velocity at some point after the turbine rotor. All wake loss models are rotational axisymmetric along the $\mathrm{x}$-axis.

Table 1. Solver setting for simulation.

\begin{tabular}{lc}
\hline Height of boundary layer $(\mathrm{m})$ & 500.0 \\
\hline Speed above boundary layer $(\mathrm{m} / \mathrm{s})$ & 10.0 \\
\hline Boundary condition at the top & fix pressure. \\
\hline Potential temperature & No \\
\hline Turbulence model & RNG k-e \\
\hline
\end{tabular}




\section{Results and Discussion}

CFD analyses are carried out at two different locations of the wind parks to estimate the AEP. Five wind turbines of type: Vestas V90 (hub height $-80 \mathrm{~m}$, each capacity $-2 \mathrm{MW}$ ) are used for the numerical study, where the analysis was carried out assuming three different distances $(50,100 \&$ $150 \mathrm{~m}$ ) between each of the wind turbines. The number of wind turbines and their capacity were chosen based on current and future settlement energy consumption. It is important to keep in mind, that population will grow, and tourism will develop. Perspective electric loads of planned-forconstruction and reconstruction objects significantly exceed existing loads. Therefore, to meet the future energy demands, the increase in energy consumption for the operational period of wind turbines was taken into account.

\section{a) Wind Resource Assessment and AEP Estimation}

Introducing new energy technologies, it is necessary to estimate how much energy can be obtained. For this, wind resource assessment is carried out and AEP is calculated. Since wind resources have not been studied before on the Solovetsky Islands, as well as on many other island territories of the Arctic zone of Russia, the wind potential is unknown. However, wind resource maps, obtained from the simulations, will significantly help to assess the wind potential of the territory. The darker color in the wind resource map means higher average wind speeds at a hub height of $80 \mathrm{~m}$, while, squares mark the potential locations of wind farms.

From Figure 7, the wind farm at location 1 is situated in the zone of stronger winds than the wind farm at location 2. Also, open water areas have the greatest wind potential. This happens because water creates a smooth surface, and the air flow has no resistance.
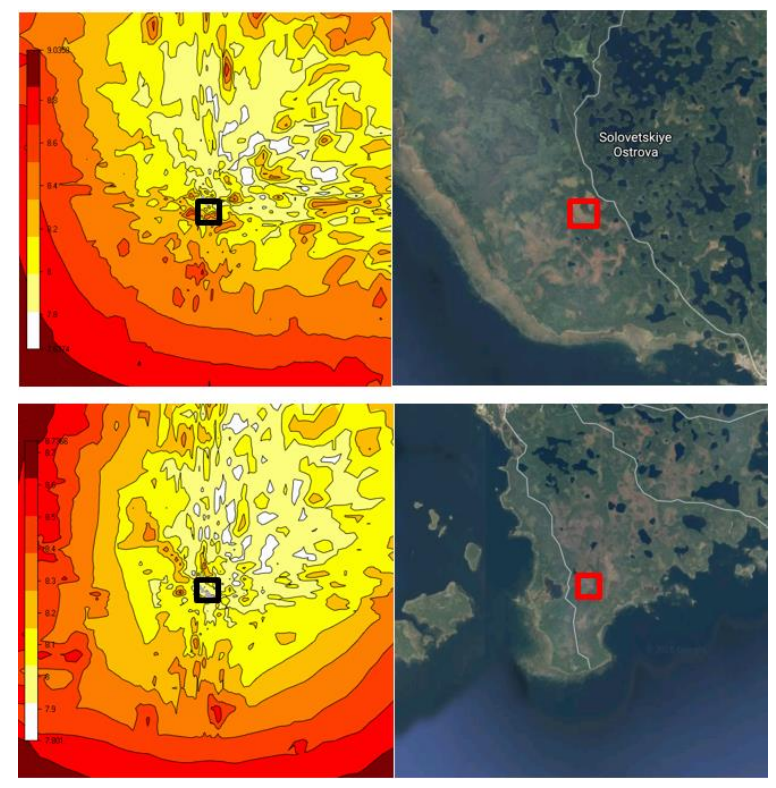

Fig. 7. Wind resource maps with average wind speed at a hub 
The AEP was calculated to numerically estimate the wind potential of the territory. Table 2 classified AEP for every case at locations 1 and 2.

Table 2. AEP results $(\mathrm{GWh} / \mathrm{y})$ for three cases at locations 1 and 2.

\begin{tabular}{cccc} 
& Case 1 $(\mathbf{5 0} \mathbf{~ m})$ & Case 2 $\mathbf{( 1 0 0 ~} \mathbf{~ m})$ & Case 3 $(\mathbf{1 5 0} \mathbf{~ m})$ \\
\hline Location 1 & 41,4 & 41,5 & 41,4 \\
\hline Location 2 & 41,2 & 41,2 & 41,0
\end{tabular}

As a result, location 1 showed the best AEP results for all three cases, which is explained by the fact that the northern part of the island is characterized by greater heights compared to the southern part.

Case results show insignificant differences between the locations, therefore another factor was implemented to justify the selection of one of the cases. Territory on the islands is limited, and accordingly every meter of land is important, and the construction area should be used as efficiently as possible. In addition, the Solovetsky Archipelago is protected by UNESCO, and deforestation is prohibited. Therefore, a smaller construction area, and accordingly a smaller distance between the turbines, would be preferable. Based on the above conditions, case 1 and the distance between the turbines of 50 meters are most acceptable.

The choice of one of the locations was made based on two parameters: AEP and wake losses. As mentioned above, the AEP for location 1 is higher and average wake losses are lower: location 1 $7.4 \%$, location $2-7.9 \%$. Therefore, for further research, location 1 case 1 was selected.

\section{b) Wake Effects on AEP}

Each wind turbine extracts energy from the wind. The wind speed downstream from the wind turbine is therefore reduced. As the flow proceeds further, the wind turbine wake spreads and recovers towards free stream conditions. When a wind park is designed, it is very important to take these losses into account and be able to estimate them correctly. The accuracy of the predicted energy production of the wind park depends on this.

In this study, three wake models (Jensen, Larsen and Ishihara) were used to estimate the wake

255 Table 3. AEP results for three wake loss model at location 1, case $1(50 \mathrm{~m})$.

\begin{tabular}{cccc} 
Wake model & $\begin{array}{c}\text { AEP without wake losses } \\
(\mathbf{G W h} / \mathbf{y})\end{array}$ & Wake losses (\%) & $\begin{array}{c}\text { AEP with wake losses } \\
(\mathbf{G W h} / \mathbf{y})\end{array}$ \\
\hline Jensen & 41.4 & 8.6 & 37.8 \\
\hline Larsen & 41.4 & 3.7 & 39.9 \\
\hline Ishihara & 41.4 & 9.9 & 37.3
\end{tabular}


From table 3, the estimated range of production losses due to wake effect varies from 3.7 to 9.9 $\%$. Looking at the AEP with wake losses, it is obvious that losses, changing even in a small range, significantly affect annual production. Therefore, it is important to optimize the wind park and to reduce wake losses.

\section{c) Seasonal Weather Effects and AEP Comparison}

In this seasonal weather comparison with AEP study part, five years of data (2013-2017) is sorted in two seasonal categories: 1) Summer (May to October), 2) Winter (November to April). For the Solovetsky Islands, the average temperature of summer climatology (May to October) was $+9.2{ }^{\circ} \mathrm{C}$, whereas, the average temperature of winter climatology (November to April) was $-3.5^{\circ} \mathrm{C}$. Varying average temperatures and mean wind speeds for five years (2013-2017) are presented in Figure 8.

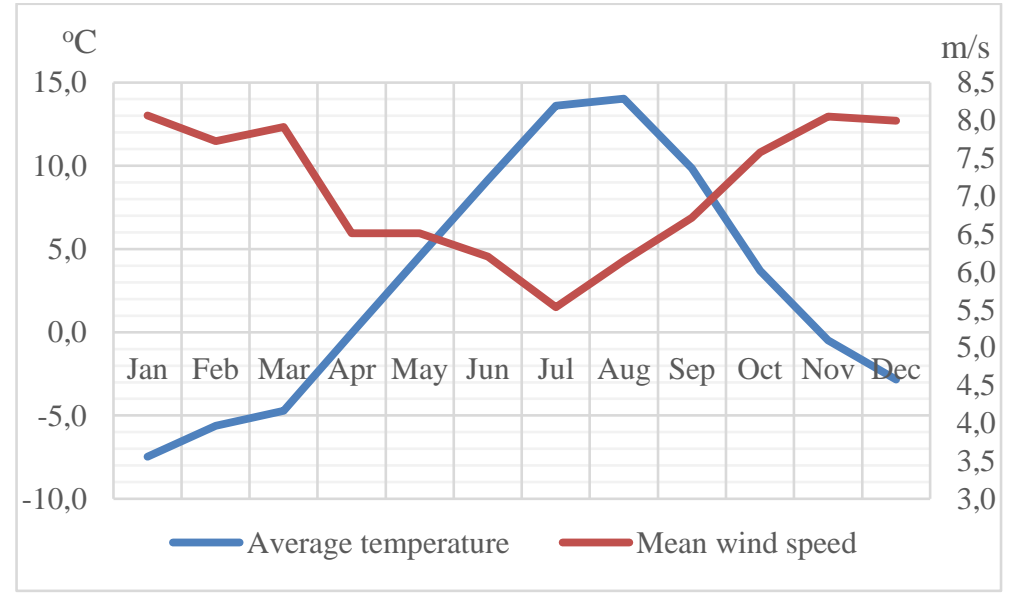

Fig. 8. Average temperatures and mean wind speeds.

The main purpose of five years seasonal categorization is to understand the atmospheric seasonal effects on power production. Five wind turbines are used to observe the seasonal effect towards measuring the power production for Solovetsky Islands.

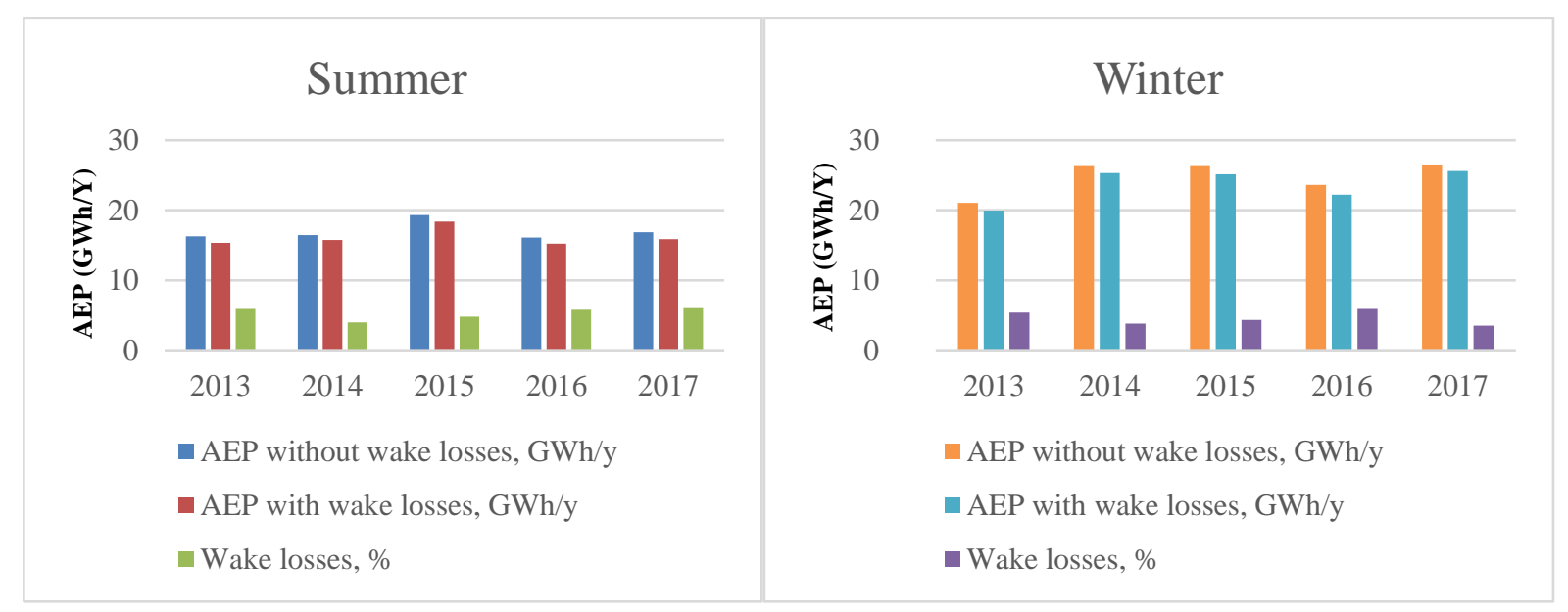

Fig. 9. Seasonal Comparison of data for five years. 
From Figure 9, the graphical representation shows that AEP during winter time is more than summer. This fact is in good agreement with the above information about the current electrical loads of the settlement (Figure 3). In winter, due to the prevalence of electrical heating, electrical loads are higher. Therefore, it can be said with confidence, that increased energy production by wind turbines in winter as compared to production in summer is concurrent with the increased loads demanded at winter season. The reason for getting more AEP in winter is due to the fact that air density in colder temperature increases and, as a result, higher production output will be achieved as more mass is passing through the turbine rotor, which has constant, finite volume. This is also an indication that for wind parks situated in cold regions, power production can be higher when compared to identical wind parks/turbines situated in warmer temperature climates. However, in order to benefit from this increased efficiency, icing-related issues and associated power losses need to be overcome.

\section{Park layout design Optimization}

The optimization of the wind park can be defined as the process of "finding the positions of the wind turbines that maximize the value of some objective function". In other words, the main purpose is to determine where to place wind turbines in order to get the maximum output from them [28].

The optimization process can be divided into two stages: the definition of the objective function and the choice of the optimization strategy. The objective function is a criterion that a wind park must meet in order to be considered optimal. The most commonly used functions are Annual Energy Production, Cost of Energy, Profit or a combination of the them. Various optimization approaches are used for finding the global maximum of the objective function. Examples of optimization algorithms are gradient method, genetic algorithms, viral algorithms, particle swarm algorithms and heuristic algorithms [28].

In this section preliminary numerical case study is carried out to optimize the Solovetsky Islands wind park and to improve the existing wind park layout. WindSim Park Optimizer is used for this purpose. Annual Energy Production is used as objective function. Park Optimizer is a numerical tool coupled with WindSim that helps to maximize the wind farm profitability by optimizing the wind farm layout.

Park Optimizer reads terrain data, flow model results and climatology data from WindSim. Then Park Optimizer processes WindSim results to map exclusion areas of turbulence, shear, flow and terrain inclinations and extreme wind as defined by the IEC 61400-1 standard. A map of wind quality aspects according to the IEC 61400-1 standard is mapped out as gray areas unsuitable for wind turbines (shown in Figure 10). These areas are used as constraints in the layout optimization. After making IEC exclusions, remaining area can be used for wind turbine placement [29]. The area for wind park can be included as shape files or drawn manually using drawing tool. 


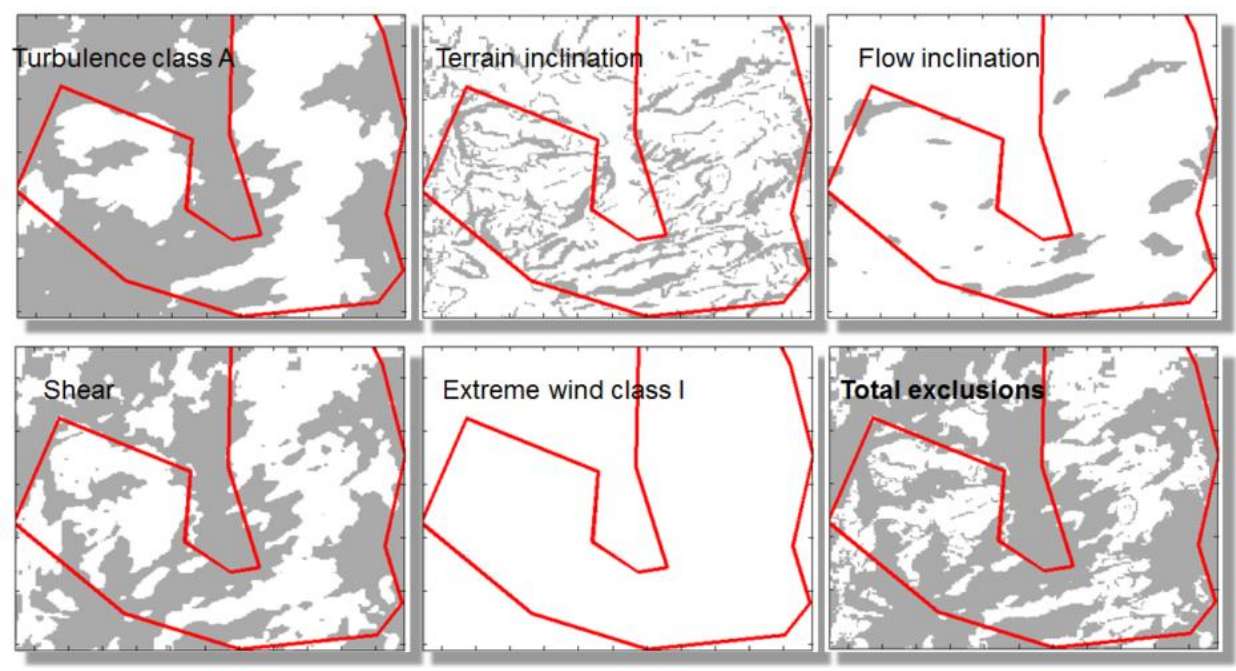

Fig. 10. Excluded areas according to IEC 61400-1 standard

Park Optimizer uses three types of optimization approaches: basic optimization, wind farm design (WFD) cloud optimization and WFD local optimization.

The basic optimization is based on a heuristic algorithm, which gives near optimal results. Three different operations are performed on the initial layout: add a turbine, remove each turbine (one at a time), and move each turbine (up to prescribed distance). After each modification, the objective function is evaluated and the layout with the highest value is kept as best candidate solution. Eventually, when a specified number of consecutive steps fails to improve the solution, the layout is considered optimal [28]. The heuristic algorithm is not always good to obtain the overall optimum, because algorithm assumes, choosing a local optimum at each step, it will end up at global optimum [30,31]. This method is slow compared to more formal optimization techniques and does not provide information about the quality of the solution. The basic optimization algorithm is default and does not require extra licenses for use.

The WFD cloud optimizer is based on formal operations research methods and has state-of-the-art optimization solvers. The WFD optimization algorithm can guarantee global optimum for layout optimization problem, subject to minimum distance, elliptic distance and wake induced turbulence constraints. WFD cloud optimization is a cloud service. The cloud optimization uploads the problem to the WFD server, that runs the optimization algorithm with state-of-the-art solvers and return the results to Park Optimizer.

The WFD local optimizer has the same optimization algorithm as WFD cloud optimizer but running on the client's local server. This alternative is intended for larger organizations and requires additional licenses.

For this case study, we used the WFD cloud optimizer. Results from WindSim simulations of location 1 presented in the previous section are used as input to the WFD optimizer. WFD optimizer 
optimally relocated the wind turbines with respect to highest average wind speed, where we can assess

337 the highest wind energy. Figure 11 shows the positions of the turbines before park optimization with $33850(\mathrm{~m})$ distance between adjacent turbines and turbines positions after park optimization.
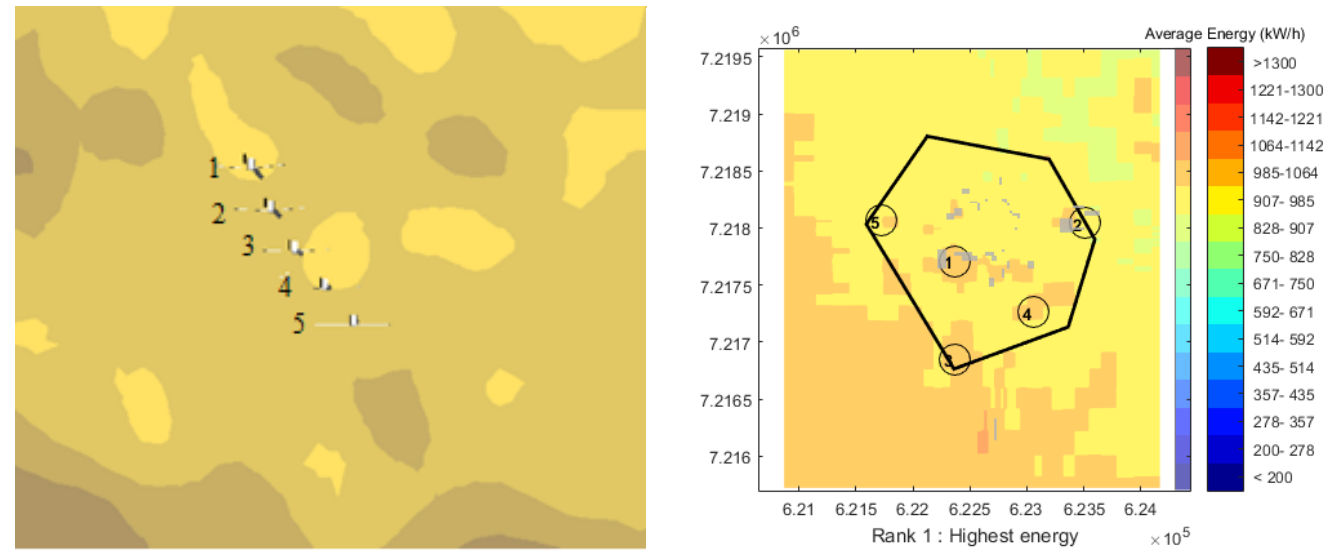

Fig. 11. Turbine position before (left) and after (right) optimization.

In Figure 11, the average energy for each turbine can also be observed. To verify the increase in annual energy production due to optimization of Solovetsky Wind Park layout, A CFD-based numerical simulation of new coordinates is carried out using WindSim. The improved AEP after optimization and AEP before optimization of location 1 for five turbines can be seen in the graphical representation in Figure 12.

From the comparison in Figure 11, AEP with wake losses of each turbine are increased. For example, AEP with wake losses before optimization is $7.9 \mathrm{GWh} / \mathrm{y}$ for turbine 1, and after optimization - $9.5 \mathrm{GWh} / \mathrm{y}$. The total AEP with wake losses before optimization of five turbines is $41.4 \mathrm{GWh} / \mathrm{y}$ and after optimization is $46.6 \mathrm{GWh} / \mathrm{y}$. Energy production increased by $16 \%$, which indicates the importance of the locations of turbines relative to each other during the design stage of a wind farm.

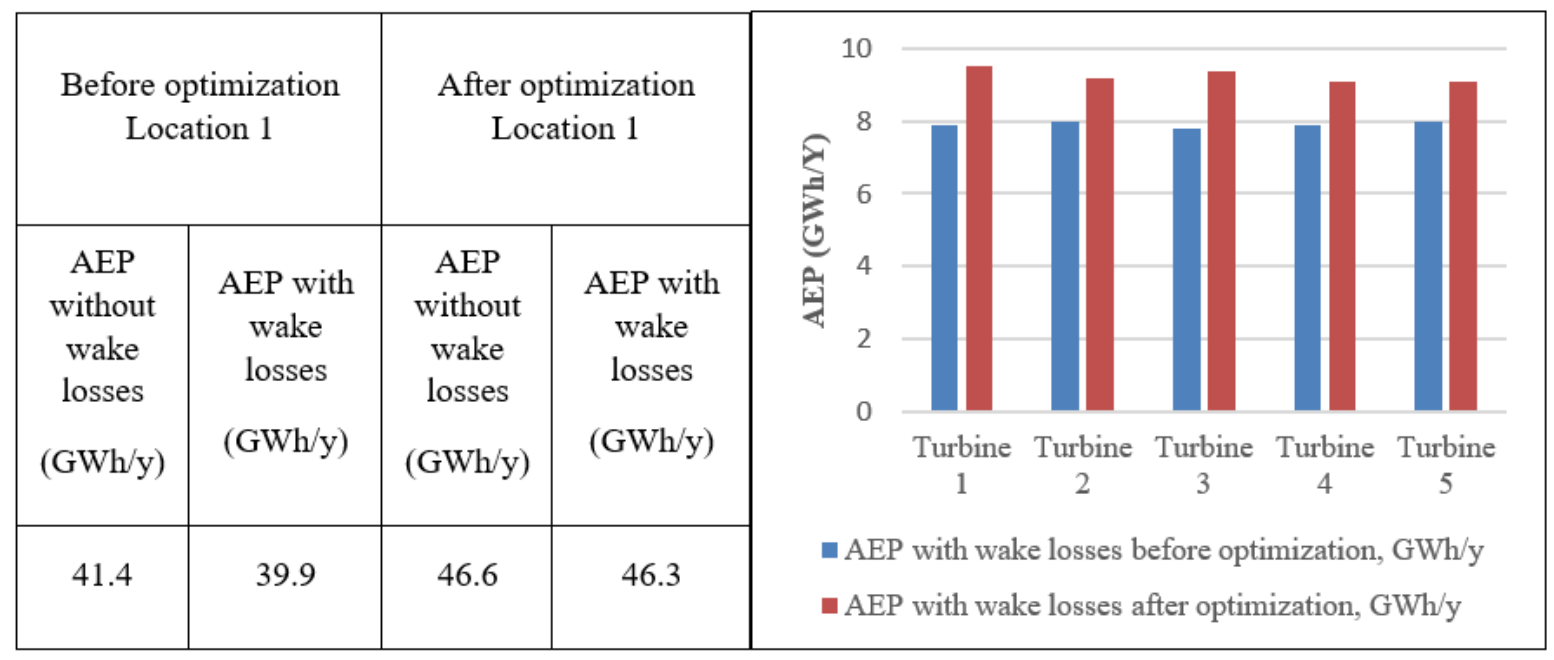

Fig. 12. Comparison AEP before and after optimization. 


\section{Conclusions}

Detailed 18-year data analysis and CFD simulations were carried out to estimate the wind resources available on Solovetsky Island in the Arctic region to assess the feasibility of setting up a Wind Park in the region. Two different locations were selected based on logistics and reduced noise pollution for settlement areas on the island. It was found that the average annual energy production of the wind farm located in the northern part of the island is higher than in the southern part, which is justified by the higher elevations of the northern part of the island. The seasonal (summer, winter) CFD simulation is carried out for 5 years data and results were compared with information about seasonal electrical loads of the settlement. Result showed that increased energy production by wind turbines in winter as compared to production in summer is concurrent with the increased loads demand in winter season. In addition, wind park optimization was carried out. A preliminary case study about wind park layout optimization shows that AEP can be increased by optimizing the wind park layout and CFD simulations can be used as a tool in this regard.

This case study will encourage the implementation of renewable wind energy technologies in remote islands in the Arctic region. Wind turbines are beneficent, reliable, one-time investment, durable time-wise and cost effective as compared to conventional power production using IC power generation technology, which imply the provision of large amounts of fuel throughout the year, emission of carbon dioxide and other pollutants as well as the additional cost of fuel logistics. The introduction of new technologies will make it possible to achieve rational use of limited energy and economic resources, ensure careful attitude to the environment and cultural heritage, and increase tourism attractiveness. As a result, it will increase interest in the development and implementation of renewable energy technologies in other regions. It is also worth mentioning that previously, no approaches have been developed in term of wind energy for the Solovetsky Islands. This case study is intended to be a benchmark for researchers and scientists in future projects.

\section{Acknowledgement}

380 This research was supported by UIT the Arctic University of Norway under Cooperative Projects 381 within the University of the Arctic (UArctic 2017) funding. The project is titled Academic 382 Collaboration for Sustainable and Energy Efficiency Development in the Arctic between The Arctic 383 University of Norway, UiT and the Northern (Arctic) Federal University (NArFU) Arkhangelsk.

\section{References}

386 [1] Boute A. Off-grid renewable energy in remote Arctic areas: An analysis of the Russian Far East. Renewable and Sustainable Energy Reviews. 59 (2016) 1029-1037.

[2] IEA - RETD (Renewable Energy Technology Deployment) Final Report; Renewable energies for remote 
areas and islands (REMOTE). iea-retd.org/wp-content/uploads/2012/06/IEA-RETD-REMOTE.pdf, 2012 (accessed 4 March 2019).

[3] Bhattarai PR, Thompson S. Optimizing an off-grid electrical system in Brochet, Manitoba, Canada. Renewable and Sustainable Energy Reviews. 53 (2016) 709-719.

[4] Elistratov V.V., Konishchev M.A. Wind-diesel power systems for standalone energy supply of Russian Northern territories. International Scientific Journal for Alternative Energy and Ecology. 151 (2014) 6271.

[5] Alkhasov, A. B. Vozobnovlyaemye istochniki ehnergii (Moscow: MEI Publishing House). 2011. P. 270.

[6] Baranov, N. N. Netradicionnye istochniki i metody preobrazovaniya ih ehnergii (Moscow: MEI Publishing House). 2012. P. 383.

[7] Da Rosa, A. Vozobnovlyaemye istochniki ehnergii ed. S.P. Malyshenko and O.S. Popel (Dolgoprudny: Publishing house "Intellect"). 2010. P. 704.

[8] Elistratov, V.V. Vozobnovlyaemaya ehnergetika (St. Petersburg: "Nauka"). 2013. P. 306.

[9] Popel, O. S. and Fortov, V. E. Vozobnovlyaemaya ehnergetika v sovremennom mire (Moscow: MEI Publishing House). 2015. P. 450 .

[10] Popel, O. S., Frid, S. E., Efimov, D. V. and Anisimov, A. M. Al'ternativnaya ehnergetika i ehkologiya Avtonomnye vetrovye ehnergoustanovki s akkumulyatorami tepla. 11 (2008) 78-85.

[11] Popel, O. S., Tarasenko, A. B. Teploehnergetika Sravnitel'nyj analiz sistem dlitel'nogo akkumulirovaniya ehnergii dlya istochnikov rezervnogo i avarijnogo pitaniya, a takzhe ehnergoustanovok na vozobnovlyaemyh istochnikah ehnergii. 11 (2012) 61-69.

[12] Tarasenko A B, Kiseleva S V, Popel O S and Titov V F 2012 Al'ternativnaya ehnergetika i ehkologiya O vybore optimal'nogo sostava gibridnoj ehnergeticheskoj ustanovki dlya izolirovannogo poselka 2 177182.

[13] Elistratov, V. V., Panfilov, A. A. Nauchno-tekhnicheskie vedomosti Sankt-Peterburgskogo gosudarstvennogo politekhnicheskogo universiteta Proektirovanie stroitel'nyh konstrukcij vetroehlektricheskih ustanovok. 3 (2007) 159-164.

[14] Bykov, E. N. and Elistratov, V. V. Izvestiya vysshih uchebnyh zavedenij. Problemy ehnergetiki Vetroehnergeticheskaya ustanovka so spiral'nymi lopastyami dlya maloj vetroehnergetiki. 5 (2007) 111114.

[15] Wiser R, Yang Z, Hand M, Hohmeyer O, Infield D, Jensen PH, et al. Special Report on Renewable Energy Sources and Climate Change Mitigation. Wind energy. Cambridge: Cambridge University Press. http://srren.ipcc-wg3.de/report/IPCC_SRREN_Ch07.pdf, 2011 (accessed 4 March 2019).

[16] Shivarama Krishna K, Sathish Kumar K. A review on hybrid renewable energy systems. Renewable and Sustainable Energy Reviews. 52 (2015) 907-916.

[17] Weis T, Ilinca A. Assessing the potential for a wind power incentive for remote villages in Canada. Energy Policy. 38 (2010) 5504-5511.

[18] Souba F, Mendelson PB. Chaninik Wind Group: Lessons learned beyond wind integration for remote Alaska. The Electricity Journal. 31 (2018) 40-47. 
[19] Nouni MR, Mulick SC, Kandpal TC. Providing electricity access to remote areas in India: an approach towards identifying potential areas for decentralized electricity supply. Renewable and Sustainable Energy Reviews. 11 (2007) 1187-1220.

[20] Galapagos San Cristobal Island Wind Project 2003-2016. Global Sustainable Electricity Partnership. https://www.globalelectricity.org/content/uploads/Galapagos-Report-2016-English.pdf, 2016 (accessed 4 March 2019).

[21] Dose B, Rahimi H, Herraez I, Stoevesandt B, Peinke J. Fluid-structure coupled computations of the NREL 5 MW wind turbine by means of CFD. Renewable Energy. 129 (2018) 591-605.

[22] Wang Q, Wng J, Hou Y, Yuan R, Luo K, Fan J. Micrositing of roof mounting wind turbine in urban environment: CFD simulations and lidar measurements. Renewable Energy. 115 (2018) 1118-1133.

[23] NASA LaRC POWER Project. https://power.larc.nasa.gov/ (accessed 4 March 2019).

[24] Kim H.G., Patel V.C. Test of turbulence models for wind flow over terrain with separation and recirculation. Boundary-Layer Meteorology. 94 (2000) 5-21.

[25] Larsen, G.C., A Simple Wake Calculation Procedure. 1988, Risø National Laboratory: Denmark.

[26] Ishihara, T., A. Yamaguchi, and Y. Fujino. Development of a New Wake Model Based on a Wind Tunnel Experiment. in Glob. Wind Power. http://windeng.t.u-tokyo.ac.jp/ishihara/e/; 2004 (accessed 4 March 2019).

[27] Impact of Different Wake Models on the Estimation of Wind Farm Power Generation http://www.utdallas.edu/ jiezhang/Conference/JIE_2012_AIAA_MAO_Wake_comparison.pdf (accessed 4 March 2019).

[28] Tesauro, A. Rethore, P.-E., Larsen, G.C. State of the Art of Wind Farm Optimization. DTU Wind Energy. 2012.

[29] Meissner, C., Vogstad, K., Horn, U. W.-S. Park optimization using IEC constraints for wind quality. EWEA, Brussels, Belgium. 2011.

[30] E. Yilmaz. Benchmarking of optimization modules for two wind farm design software tools. Master's thesis, Gotland University, 2012.

[31] U. A. Ozturk and B. A. Norman, "Heuristic methods for wind energy conversion system positioning," Electric Power Systems Research. 70 (2004) 179-185. 